\title{
Physiological Mechanisms Relevant to Genetic Improvement of Salinity Tolerance in Crop Plants
}

\author{
G. V. Subbarao and Chris Johansen

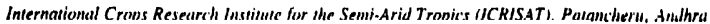 \\ Proulesh. Indial
}

\section{INTRODUCTION}

Crop species differ widely in their ability to grow and yicld under saline conditions. However, almost all crop plants belong to the glyeuphytic category, except for a few crop species such as sugar beet, which has halophytic ancestors. By ccological definition, halophytes are the native fora of saline habitals III. From a crop improvetnent perspective, the variability for salinity tolerance within a crop species or among its wild relatives is important. It is also important to understand the physiological mechanisms of salinity tolerance operating within a crop species so that suitable breeding strategies can be developed for improving salinity tolerance. There are several reviews covering the general responses of plants to salinity stress and the mechanisms available in halophytes and glycophytes which allow them to cope with saline habitats [2-7). However, litule attempt has been made to integrate information on these physiological aspects into genetic improvement concepts.

Salinity creates stress by reducing the osmotic potential of the rovting medium and increasing ambient concentrations of ions such a $\mathrm{Cl}, \mathrm{SO}_{4}, \mathrm{CO}_{3}, \mathrm{HCO}_{3}, \mathrm{Na}, \mathrm{Ca}$, and $\mathrm{Mg}$. Being glycuphytes, crop species have no appendages, such as salt glands, bladders, or hairs, that excrete salts absorbed in excess from their shoot lissues. The limited compartnentation ability of the shoot deitiands otrict regulation of ionic delivery to the shoot. Physiological mechanisms controlling sali absorption and distribution in crop plants, and the osmotic adjustment that is essential for turgor-driven water uptake, are covered in this chapter. We specifically address the questiun of how information on these physiological mechanismis could be utilized in genetic improvement programs as an integrated approach to improving salinity tolerance in a given crop.

\section{REGULATION OF ION TRANSPORT}

Plants regulate their intracellular ionic composition to maintain a suitable ionic environnent tor the physiological and biochemical processes that proceed within a cell. This internal enviromment 
nceds to be maintained within acceptable limits if plant growth and function are to proceed in saline envirunments [8]. Salinity under field conditions is characterized by a mixture of salts. Herwever. $\mathrm{Na}$ and $\mathrm{Cl}$ are predominant in most situations. Therefore, most studies of salinity effect efer to $\mathrm{NaCl}$ salinity as a model system. although the effects of all ions that are in excess in saline environment in nutrient uptake are recognized. Similarly, due to the importance of $K$ in plant nutrition and hecause the effects of $\mathrm{Na}$ on $\mathrm{K}$ uptake have becn studied extensively, we refed primarily in this interaction in our discussion of ion uptake nechanisms.

\section{A. Regulation at Root Membranes}

The concept of dual mechanisms of ion transpent is a useful framework for describing ion uptake |ग. At low concentrations of $K$ in the extcinal solution. below $1 \mathrm{~m} M$. uptake of $\mathrm{K}$, described by a discrete Michaclis-Menten kinetic equation. is thought to operate at the plasmalemma. We shall call this mechanism 1 . At $\mathrm{K}$ concentrations in the range 1 to $50 \mathrm{mM}$, mechanism? "perates. Mechanism 2 is thought to involve diffusive, or at least nonselective ion movemen acrose the plasmalemma with the rate limitation inward from the plasmalemma, probably at the 1.nnylast 19\}. For mechanism 1. there is a high selectivity of the active transport mechanisa fur $k$ aver compeling cations such as Na. For mechanism 2. this level of selectivity is no pescm. Mechanism $l$ is net influcnecd by the concomitant counteranion, but mechanism 2 is Fir e rample. compared with $\mathrm{Cl}$. $\mathrm{SO}_{4}$ severely depresses $\mathrm{K}$ absorption at $\mathrm{K}$ concentrations is the range of mechanism 2 but not in the range of mechanism I. This dual phenomenon of ios wiplake has been elescribed for various plam and ionic species (sec p. 136 of Ref. 9).

Selective ion tancpurt. at least in the range of mechanism 1. depends on metabolic energ. derived from adenosine triphosphate (ATP). This allows charge separation across cel ncmhranes. through prinury transpurt of $11^{*}$, thus creating a lucalized electrochemical gradien

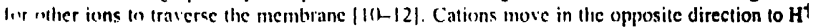
tantiport). while anions are co-transported with it (symport) or nove as antiport to $\mathrm{OH}^{-} \mathrm{O}$ III $(1 ;$; [13].

Selectivity between innic specics is governed by the particular binding properties of cel membrane constituents. Little is known about this process. duc to limited knowledge of plan mirmbrane structure and function |1.3-15| Breakthroughs in this regard will allow for a understanding of the molecular basis of ion transpurt and the effects of salinity on this process The entry of $\mathrm{Na}$ or inther ions in excess in the ambient solution can be controlled by this selectiv hinding. An alternative for regulating $\mathrm{K} / \mathrm{Na}$ levels inside root cells is by means of an outwardl directed $\mathrm{Na}$ pump at the plasmalemma $|2.16-18|$.

In most situations. siline or otherwise. Nat movement across the plasmalemma into root cell is herught in te pascive down an clectrochemical gradient |7|. For exauple. the membrane leakag of Na accounts for the cyloplasmic Na levels found in rice || $9 \mid$. Jeschke $|6|$ has proposed a mode i.. explain K/Na exchange at the plasmalcmma (Figure 1). the components of which are:

1. A proton pump powered by ATP generates an clecirical potential difference and proto gradient acrose the plasmalemuna.

$2 \quad$ The electrical charge of $I 1$ is compensated by an influx of $K$ at a specific site or channel This site has a lower affinity for $\mathrm{Na}$.

? The proton gradient provides energy for extrusion of $\mathrm{Na}$ from the cytoplasm by a $\mathrm{H} / \mathrm{N}$ antiport: this site is reported to have a lower affinity for $\mathrm{K}$.

There is variation among crop species in their $K / N a l$ exchange capability $[6,20]$. Barlej "Ircat. and rye showed efficient K/Na cxchange compared to sensitive species such as Alliu IrT" and Heliammis ammms [20]. The existence of genotypic differences in this trait within 


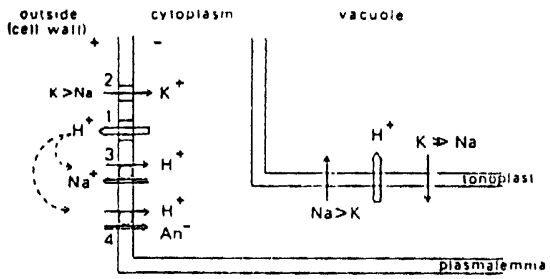

Figure 1 Mlodel of the proten-mediated $K / N$ a cxchange system at the plasmalemma and Na. $K$ sashange

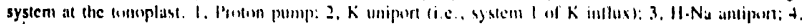
$H^{+}$-anion sympurt. (From Rat. 6)

crop species and its relation to salinity tolerance is not know'n. Such intormation is vital to an evaluation of the polential utility of this trait in genetic improvenent programs fier sulinity tolerance. The relation belween K/Na selectivity and salt folerance has been revielled $[2-4,21-23]$. Variation in K/Nal exchange suggests at leasl quantitative difierences in membrano properties among different crop species $|0|$. The genetal response of many crop planis to a moderate increase in external salinity is increased plant $\mathrm{K}$ levels and reduced $\mathrm{Na}$ concentrations in tolerant relative to nomblerant genusypes $|2+-20|$.

For the high-affinty ystem mediating $k$ inllux (f.potein's mechanism 1), a proton pump appears to be present in the plasmalemma of rost contical eells $|6|$. llowever, the graded response of Na-eflux (1) adsed $K$ stuggests quatntitative diflerences between species, and perhaps annong genotypes of a crop species, in the number and elficiency of sites mediating the $1 \mathrm{l} / \mathrm{Na}$ antiport [6]. The number of sites for the Il/ $\mathrm{Na}$ antipon neels 10 be guamified and the existence of genotypic variation within a crop species estimated to decermine the feasibility of favorable genetic manipulation of this trait.

At $\mathrm{K}$ concentrations above I mMt, in the range of mechanism 2, seleciivity is diminished in the face of competition from sther ions, such as $\mathrm{Na}$, in the ambient medium. Whether this is due to increased passive movement of all ambient ions across the plasmalemuna. down an electrochemical gradient, or less selectivity in an active transport process remains unclear $|9|$. Eventually, however, if ambient salt concentrations reach high enough levels, membranes would become conipletely permeable. Information on species or genotypic differences regarding the level at which such physical disruption occurs may also provide a guide to sclection for salinity tolerance $\{30,31\}$.

Most of the kinetic studies referred to above were carried ut on tissue previously starved of salts (low' salt status). However, as cyloplasmic concentrations of absorbed ions increase, influx rates slow down. indicating a feedhack mechanism controlling active influx of ions [13,32]. For example, $K$ concentrations in the eytoplasm of normally growing plants are

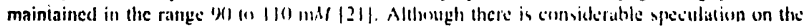
nature if such feedhack mechatisum |1.3|. their further understanding would also assist in selection of genotypes that hetter comtrol their ion transport processes at the plasmalemna.

\section{B. Intracellular Compartmentation in Roots}

Vacuoles occupy more than $80 \%$ of a mature root cell's volume and thus provide a means of osmotic regulation for ront tissuc $\{3.3\}$. This is achieved by conıpartmentation of inorganic salts, 
primarily because these are metabolically inexpensive compared to organic solutes. Salt is meve acrnss memhranes inere casily than do molecules of large molecular weight. Theros conciderable metabolic corsts in transporting photosynthates from the shoots for use as osmog in reots [34].

Inorganic ions contrihute substantially to osmotic adjustment in root cells of glycophy under saline conditions. llowever. the amount of osmotic adjustment varies from one spec in ancther and coruld the an important factor in decermining salinity tolerance. Roots of ma elyeophytic crop species sontain sustantially higher levels of $\mathrm{Na}$ and $\mathrm{Cl}$ under saline conditic than $\mathrm{d}_{0}$ shonts $[24.35]$. In pigeonpea (Cajamus cajan) and its wild relatives, the most toler genertypes retained higher levels of $\mathrm{Na}$ and $\mathrm{Cl}$ in the roots, and this was associated with salin tolerance in this crop 29.36 . Ability to retain $\mathrm{Na}$ and $\mathrm{Cl}$ in roots breaks down at a gin concentration. leading to large-scale translocation of these ions to the sloot, with resultant $p$ l mortality. This critical level varies between pigeonpea genotypes and between pigeonpealy its wild relatives. and is considercd a determinant of the level of salinity tolerance [29]. "4.

The cyloplasm shows a strong sclectivity for $\mathrm{K}$ over $\mathrm{Na}, \mathrm{Mg}$ over $\mathrm{Ca}$, and $\mathrm{P}$ over $\mathrm{Cl}$ NO, 227.37$]$. Optimal concentrations for various ions vary in the cytoplasm: thus when is enter the protoplast atovec this concentration. they may be actively transported through.i innoplast intn the vacuole. Ilowever. lliese ions cuuld be recuvered from the vacuole, depend on the metabolic requirements in other plant parts. Retranslocation of $\mathrm{K}$ is one example $\mathbf{6}$

Vacunles play an important role in maintaining stable lcvels of various inorganic iona the cytoplasm. hy acting as a sturage reservoir for these ions [33]. Under $\mathrm{NaCl}$ salinity, and $\mathrm{Cl}$ are nurmally the predominant ions entcring the protoplast of root cells. These ions actively pumped into the vacuule after reaching a threshold concentration in the cytoplas This wevuld reduce the foow into the $x y i c m$ of $\mathrm{Na}$ and $\mathrm{Cl}$ and of other ions associated $\mathrm{x}$ salinity (e.g.. Ca. Mg. S() $)_{1} \mathrm{CO}_{3}$ ) and thus restrict their translocation to the shoot.

The general hypothesis is that $\mathrm{Na}$ and $\mathrm{Cl}$ must be excluded from the cytoplasm. Thi hased on the sensitivity of enzyme activitics to high $\mathrm{NaCl}$ levels in vitro [7]. High levels of in the cytoplasm are reported to interfere with $\mathrm{K}$ metabolism. resulting in ionic toxicity; be is not known what $\mathrm{Na}$ levels are biochemically compatible with other cytoplasm solutes I In com, cytoplasnic Na cuncentrations can reach 40 to $70 \mathrm{~m} / \mathrm{f}$ under nonsaline conditions [2 hut can rise to $/ 4(1) \mathrm{mA} /$ under $\mathbf{l}(0) \mathrm{mM} / \mathrm{NaCl}$ external salinity and become toxic to the pla In reots of the haluphyte Triglochin maritima exposed to $500 \mathrm{mM} \mathrm{NaCl}$, the $\mathrm{Na} / \mathrm{K}$ ratio only 2 in the cytorlasm compared to 15 in the vacuole, although there was approximately mif $\mathrm{Na}$ in both compartunents [38]. Thus the solerance of the cytoplasm to $\mathrm{Na}$ can vary betw species. As long as tissuc $\mathrm{Na}$ concentration is below the level acceptable for the cytopla more eophisticated compartmentation may not be necessary [7].

There are several factors that conuld mitigate the adverse effects of excess ions in cytoplasm. One is the type and yuantity of organic solutes that could modify the tolerance it of cytoplasm to monovalent cations such as $\mathrm{Na}$. Another is the existence of isoenzymes many enzyme systems, which may have different tolerance thresholds in the cytoplasm. In. mayx. although the total acid phosphatase activity was slightly reduced under salinity, cer iscrenzymic forms of acid phosphatase increased in different plant parts 1391. Similarly, relative proportions of malate dehydrogenase isoenzymes were changed during salinity st in pea seedlings $[40]$.

In sunflower. a plastome mutant line that has higher resistance to salinity than that o parental line. reportedly produced a unique isoenzyme of peroxidase under saline condit: 1411. This isoenzyme was found to be resistant to $\mathrm{NaCl}$ or $\mathrm{Na}_{2} \mathrm{SO}_{4}$ salinity up to $1.2 \%$ 2.47 respectively in vitro. Cavalicri and Huang |42| reported that enzymes isolated from $n$ were distinctly more tolerant to $\mathrm{Na}$ than those from the shoots: these results might reflect $\mathrm{O}$ 
differences between shoots and roots and in compartmentution between cyluplasm and vacuule [33]. Another possibility is that certain isoeneymes exist only in certain plam parts; for exumple, the isoenzyme patterns of shoots could be difitrent isum thuse of renis $\mid+3$. Thus the stalement which is often made-that "there are no vifiererices in enzyme systems wit halophyles and nonhalophytes in their tolerance to monovalent cations in vitro" $|3,21,+4-16|$, needs lu be reexamined.

Another aspect of the adaptation of higher plants 10 salinity is compartmentation within the cytoplasm, because the cytosol is particularly sensitive to tlucluating salt levels |3.5| Fur cells involved in salt transpor, the rough endoplasmic reticulum (Rl:R) prosides a compartment within the cytoplasm in which salt may be seguestered $|35|$. Sulnsiunces can be transpurled symplastically through the Rlik, vid desmonubules. This ma alsu provide a means of ion transfer to vacuoles without disrupting ion concentruions in the cy'losul, us RER cisternat may fuse with the tonoplast, releasing their contents intu the vacuole $|3.3|$.

Several hypotheses have been proposed to explain the mode of ion transpurt fiom ejtuplasm to vacuole through the tonoplast. Pitman and Siddler [16] liceated an inwardly direcied $N_{\text {is }}$ pump at the tonoplast that would effectively deplete $\mathrm{Na}$ levels in the cywplasm. Jerinings $\{+7\}$ proposed a very similar model for transport of $\mathrm{Na}$ lrum the cytoplasm into the vacuole by neatis of $\mathrm{Na} / \mathrm{K}$ exchange. Proton punps powered by ATP are also thought in play a crucial rule in generating the transmembrane electroclemical potential difierences required to energize

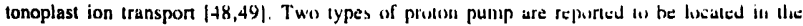
tonoplast; they are catalyzed by functionally and physiologically distinct phuspliohydraliuses: (p-ATPase and tp-PPase (tonoplast pyrophosphatase) [+8].

Exchange of $\mathrm{Na}$ and $\mathrm{K}$ at the tonoplast can occur only while $K$ itmains in the vacuade $\mid \mathrm{n}$ |.

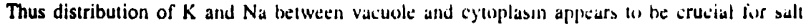
tolerance $\{21,23\}$, and since vacuolar $K$ concentration represents a pelcutial reservoir thal cuald be removed by exchange for $\mathrm{Na}$, the allocation of these ions needs lu be retgulated. However. the vacuole of root cortical cells is in some respects a dead end; comtimued selective transport across the root depends on selective transport at the point of entry of salts indu the cyluplasm, which depends on the ability of the plasmantembrane lo restrict passise intlux of sodium abd maintain high $\mathrm{K} / \mathrm{Na}$ selecrivity [.50). Thus without control of the qualtity of salt that is allused into the root or that reaches the leaves, intracellular compartmentation eitler al row sorted or in the shoot would in any case be a very limited option [7]. The vacuolen's role may be tuwre in using $\mathrm{Na}$ as an osmoticum instead of $\mathrm{K}$ and in providing a source of slored $\mathrm{K}$ ' under salinizistion rather than as part of a selective system of salt transport ucross the twit |su|.

\section{Regulation of Long-Distance Transport to Shoots}

Beyond the plasmalemma, there are several other possible barriers that could minimize transport of excess salts to the shoots. An impontant one is movement of silts trom aylem puretuitisnis cells into the xylem stream. Evidence favors this process being medialed by active traisporn [9], with the possibility of iurther selectivity in ion transpon. Xylem parefichyma cells isll he

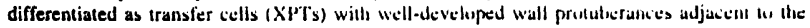
bordered pits of xylem vessels in the proxinal region of roots and stems. These are repuried in Phaseolus coccineus |35\}, Glycine max |51], maize $\mid 52,53\}$, and sijuash |5+1. These transier cells accumulate $\mathrm{K}$ in the absence of $\mathrm{NaCl}$ in the growilh medium and $\mathrm{Na}$ under saline $(\mathrm{NaCl})$ conditions [51].

A salt-induced formation of wall ingrowths has been reported for xylen parenchynia cells in soybean $[51,55)$ and tor the root epidermis cells of Phaseolus coccineus [35]. Xylem parenchyma cells and transfer cells are both capable of restricting silutes, purticularly $\mathrm{Na}$, by 


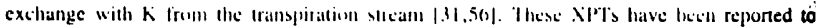

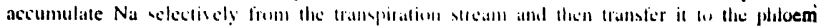

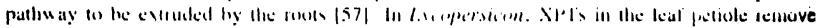

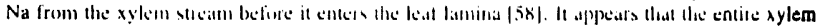

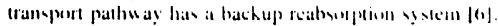

The cyllplasm of the transfer cell contian cisternat of RE:R which increase under $\mathrm{NaCl}$

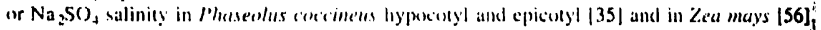
RER could pernit a large flow of iom lhrough the cytoplasm of xylem parenchyna cells assuming that ions are localized mainly in the vacuole |3|. The quantitutive significance of thif reabsorption process from the xylem in regulating Na-ion transport to the shoot is not known

The ability of XPTs to ahsorb $\mathrm{Na}$ is finite and coruld be exhausted rapidly under saline conditions $|59|$. Some lateral redistribution is possible, lowever, hut this may not be sufficieni to prevent $\mathrm{Na}$ from eventually reaching the shou $\mid(0)]$. However. XPl's have a limited capability 10 store $\mathrm{Na}$, and this $\mathrm{Na}$ needs to be removed to the lateral tissue for XPT to continue absorbing $\mathrm{Na}$ from the transpiration stream. This $\mathrm{Na}$ could be loaded into the phloem and translocated to the roots, where it could either be further compatmentalized or extruded. Such Na extrusiog has been reported in $H$, vulgare $|16,18.61|$ and $P$. vwlguris |62]. Thus the practical significanc of XPT cells in the basal part of the stem may be limited in controlling $\mathrm{Na}$ flow into the shool (1) a low degree or a short duration of silinity wress $\mid 6,3,6.4)$. The existence of quantitative variation in X'Pl's among genutypes in Ielation lu differences in salinity tolerance is not known'. Such knowledge is necessary (1) evaluate the usefulness of this trait from a genetic improvemea perspective.

\section{Apoplastic Salt Accumulation}

Oenti |6,5| predicted that apoplastic salt lowd coulal cause water deficit and lurgor loss in lead cells and proposed it as a mechanism of salinity damage. This concept has received renewex interest $|4.66-68|$. Under saline conditions, $\mathrm{Na}$ and (il can bypass the ion transport contro mechanisms discussed earlicr, be cartied upwatd in the xylem stream, and be delivered to the apriplasts of leaf cells $|69|$. If shoot protoplast atcumulates these ions beyond levels that an tolerated in the cytoplasm and its compantmentation capacity of the vaçuole, disruption of the metabolic functions due to ionic loxicity would result (70)]. On the other hand, a failure to de so would lead $t o$ ion accumulation in the apoplast. which could reach very high levels in ! short time. as the apoplast occupies only $1 \%$ of the cell's volume $\{65.70\}$. For instance, evei if 907 of the $\mathrm{NaCl}$ arriving in the $x$ j lem (plamts grown at $50 \mathrm{maN} / \mathrm{NaCl}$ external solution) $\mathrm{i}$ accumulated in the protoplast. the ajuplastic concentrations could reach $500 \mathrm{n} / \mathrm{f}$ within 7 day $\left.|7|\right|_{\text {and }}$ cause cell death. although the average tissue $\mathrm{Na}$ and $\mathrm{Cl}$ concentrations may not reacl I(K) m/l. Because of the small apephast volume. such ion concentrations in the apoplast couln excur at overall low tissue concentrations and would thus escape detection in slandard tissu analysis $\mid 7(0)$. Excessive accumulation of salts in the leaf apoplast would cause turgor loss stomatal closure, and cell dehydration.

Water deficits in a particular leal, as opposed w the plant as a whole, could be an inevitabl consequence of increasing apoplastic salt load $[0,5]$ and will occur whenever the rate of arrivs of $\mathrm{NaCl}$ in the xylem is greater than the rate of accumulation of these ions in leaf cells [67] Thus arguments that plants have adjusted osmotically to external salinity, which are based 0 comparisons of solute concentrations in tissue water with external salinity, need to be viewe with caution [71]. The success of a crop species in surviving and reproducing under salin conditions depends considerably on its ability lo regulate ion delivery into the xylem strea without causing ion toricity in leaf protoplasts or apoplastic salt buildup |70]. Cienotypes th 
could more effectively transfer $\mathrm{NaCl}$ from leaf aproplast into leaf cells would be at an advantage. Although this increases their proteplast salt concentrations due to the relative volumes of protoplast and apoplast, this is considered tw be less serious than the conseyuences of apoplastic salt buildup $\{19,7(1)\}$.

\section{E. Phloem Retranslocation}

When $\mathrm{Na}$ or $\mathrm{Cl}$ levels in the cy'toplasm of mescopliyll cells reach a tolerance theshold and heir compartmentation capacity hecomes saturated, additional $\mathrm{Nat}$ or $\mathrm{Cl}$ ions can immediately be transported hy intraveinal recyeling so as to prevent apoplastic buildup of $\mathrm{Nas}$ or $\mathrm{Cl}$ or ion toxicity in the cytoplasm $|6+|$. Since there is no harrier hetween the sy lem and the leaf apoplast [72]. ions can be actively loaded into phloem vessels 17.31. This mechamism may play a significant role in the regulation of $\mathrm{Na}$ or $\mathrm{Cl} \mid \mathrm{ions}$ in lle shese $\mid 54,62,7+1$. Bascol on cytoplasmic $\mathrm{Na}$ concentrations, it has been estimated that nearly $25 \%$ of the $\mathrm{Na}$ entering the leaf can he retranslocated by the phloem [33]. Ilowever, phloem kadling and retranslecution of $\mathrm{Na}$ or $\mathrm{Cl}$ is seen as metabolically expensive. Large quantities of $\mathrm{Na}$ or $\mathrm{Cl}$ in phloem rellests poor control at the root level in regulating ion How into the xylem. This was found in stulies by Lessani and Marschner 175), Where phlecen translocation of $\mathrm{Na}$ or $\mathrm{Cl}$ is greulest in sensitive species such as bean, and least in Inlerant species such as harley and sugar beel 1271.

Among a range of species. Here was a significant correlation betwesl a decededse in dry matter production at $1100 \mathrm{mMI} \mathrm{NaCl}$ in lie medium and $\mathrm{Na}$ retranslociation from leaves. particularly, efflux from routs (Figure 2) $17.5 \mid$. If incoming ions are excessive to the shoures compartmentation ability and the phloem translocation capacity. overloading of $\mathrm{Na}$ or $\mathrm{Cl}$ ions into the phleem parenchyma transfer cells could occur. This would tesult in destruction of phloem transfer cells $|6+, 76|$. Although phlocm retranslocition dess contribute to regulation of $\mathrm{Na}$ or $\mathrm{Cl}$ levels in the shout. it appears to have a limited role in this tegard and thus in determining the level of salinity colerance. Regulation of $\mathrm{Na}$ and $\mathrm{Cl}$ levels in the shoor lies primarily with the rest's ability on regulate $\mathrm{Na}$ or Cl thow into the xylem. rather than the shosel's ability to retranslecate to the r(x)t $|5 \%|$.

Availability of sufficient $\mathrm{K}$ in growing and expanding regions of the shoot and root is crucial to maintenance of $\mathrm{K} / \mathrm{Na}$ selectivity and subsequent $\mathrm{Na}$ compartme'utation in the root cortex. In addition to efficient $\mathrm{K} / \mathrm{Na}$ selectivity at the plasmamembianc, phlocm transport of $K$ reserves within the plant plays an important role in salinity tolerance. Potassium is remobilized from mature leaves by removal of vacuslar $K$ through $\mathrm{Na} / \mathrm{K}$ exchange at the tonoplast of mesophyll cells. This $K$ is then retranslocated to the growing regions of the root, shoot, and expanding leaves, where there is little vacuolar space and the cy'toplasm occupics a major portion of the cell. These growing zones require large quantities of $K$ to theet their denands for osmotic adjustment in the rapidly expanding vacuolar sprace. Leas es develop and expand close to the shoot apex and derive their mineral nutrient supply from the phlsem twhich is rich in $\mathrm{K}$ ), particularly since phloem lissue differentiales prior 10 xylem elements 1777 . With increasing leaf age, minctals are imported mainly by the xylem. Which is high in $\mathrm{Na}$ lescls

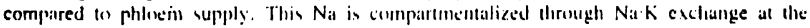

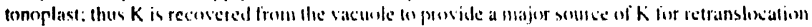
[23].

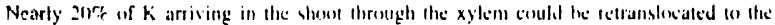
growing regions of the rewt. Whete high $k$ levek alle essential |fol. Such $K$ retranslocation has been reportẹl in barley $|7 x-(x)|$. (1)matoss, and lupins $\mid(1)$. The atsility 10 remobilize and retranskocate $\mathrm{K}$ into the growing region of the rove and showe plays an impontant role in $\mathrm{Na}$ comparmentation in the rous cortex and in maintaining a high $\mathrm{K} / \mathrm{Na}$ ratio in shoot growing 

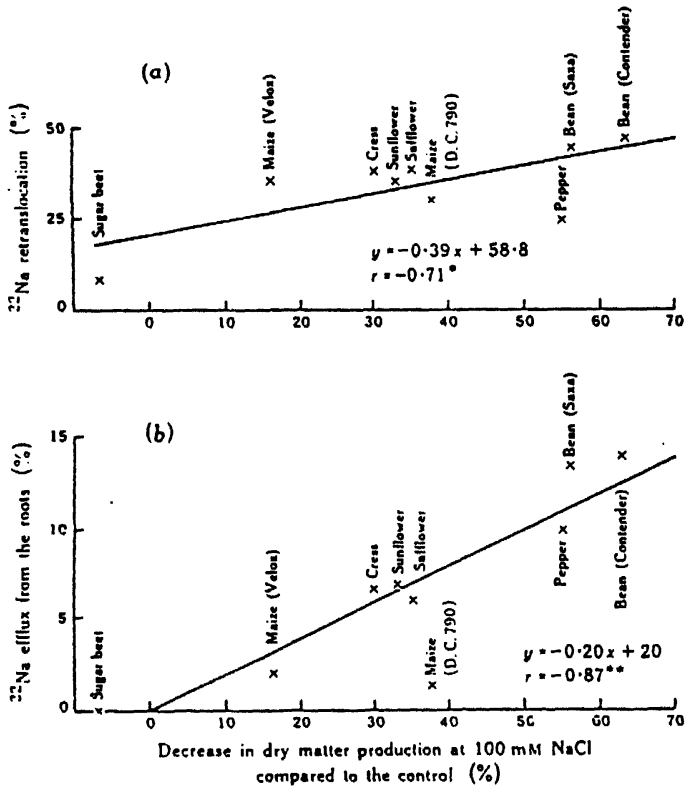

Figuie 2 Relationship betucen decrease in dry matter production and (a) Na retranslocation and (b) effluy of $\mathrm{Na}$ frmm riwrs. in species differing in their tolerance to salinity. (From Ref. 75)

regions. thus protecting them from $\mathrm{Na}$ or $\mathrm{Cl}$ toxicity. Miost tolerant crop species, such as barley anj sugar beet. have a very efficient $K$ recirculation system which is tightly linked to $\mathrm{Na}$ regulatory mechanisms. This mechanism may also be important in determining genotypic differences in salinity response.

\section{F. Role of Transplration}

Shrwe ion concentrations are a product of transpiration rate, xylem ion concentrations, and griwith rate $[81\}$. Under high evapotranspirational Jcınands. transpiration increases, while $K / \mathrm{Ne}$ selectivity decreases, resulting in inereased $\mathrm{Na}$ and $\mathrm{Cl}$ uptake (82.831. Alternatively, a reduction in Iranspiration can decreace ion ( $\mathrm{Na}$ and $\mathrm{Cl}$ ) uptake $[6.27 .60\}$.

There are a number of hypotheses proposed to explain increased xylem sap $\mathrm{Na}$ and $\mathrm{Cl}$ levels under high evaputranspiration rates in saline growth media. Enhanced water flow interacts 
with ion flow across membranes of root cells at more than one site, thus interfering with processes that regulate the balance between inn accumulation in the root cell vacuole and transport to the shoot [6]. Increased water flow due to transpiration promotes passive ion movements where there is no active transport barrier $[84]$.

Water flow can promote the ion flow across the corex toward a pump that secretes ions into xylem vessels [80]. Ions could either be moved hy water along an apuplastic pathway at high concentrations or be coupled to water flow during symplastic passage acruss the root [85]. High transpiration rates increased $\mathrm{Na}$ transport more than $\mathrm{K}$, thus shilting the selectivity tow'ard $\mathrm{Na}[\mathbf{8 6 , 8 7}$. Potassium ions absorbed in roots may he released through $\mathrm{Na} / \mathrm{K}$ exchange, mainly from vacuoles, for transport to the shoot at times of high evaporative demand |6].

In halophytes, the entry of ions such as $\mathrm{Na}$ or $\mathrm{Cl}$ into the roots or their release to the xylem sap is tiglatly regulated at high evapxtranspirative demand under saline conditions. thus regulating ion supply to the showt. Certain morphological features, such as increased width or early development of Casparian strips $[88]$ or formation of a double endodermis $[89,90]$, have been reported to develop under high cvaporative demands, thus minimizing the passive influx and bypass flow of $\mathrm{Na}$ and $\mathrm{Cl}$ ions into the $x$ y len. We are not aware of such allutomical chunges reported in any crop species under saline conditions. I may be worthwhile to exantine genoty pes that show high salinity tolerance for sucli kinds of adaptive features. Since water use is tiglitly linked to ion uptake and selectivity. the morphological and physiological traits that increase water use efficiency (WUE) in a given genotype could have a role in determining salinity tolerance [81]. In rice, genotypes that showed higher WUE also have a higher level of salinity tolerance $[81]$.

\section{ORGANIC SOLUTE ACCUMULATION}

A wide variety of organic solutes have heen reported to aecunulate in plant tissues during water

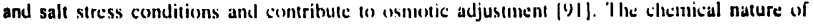
the compatible solutes varies from one taxonomic group to another, but most are derivatives of polyols or nitrogen dipoles [27| (Table 1). Osmotic adjustment by the plant promotes turgor maintenance and is thus associated with adaptation to both high soil salinity and low soil moisture $[4,92 \mid$. Compatible solutes are an important factor in the osmotic balance of the cytoplasm under salt stress $|21|$, where sodium salts are sequestered to play a coniplementary osmotic role in the vacuole $[3,2\}, 23\}$. However, this is considered to be a halophytic mode of osmoregulation [93]. which is energetically more efficient than overall osmoregulation by organic solutes $[5,94)$, which is a common feature of glycuphytes $|91|$.

These organic solutes nay comprise common metabolites such as sugars, amino acids such as proline [95-98], and organic acids such as proline betaine 199 ) and other aliphatic quaternary ammonium compounds $[\mid 0())$. There is evidence that solute accumulation is a regulated process and not merely the result of a discrepancy between the sensitivity of the grou th process and phmosynthesis to stress $|101|$. Nevertheless, metabolites such as glusose and sucrose aceuniulate in tissues whose growh has heon inhibiled by stess [91].

The type of etress would setermine which compound, act as osmotic solutes [102]. In grain enghum, hetaine accumulates anly uncler moderate levels of salt stess, not under water stress $\$ 10.2$. However, in crops such as wheal, harley, and rge. helaine accumulates under water stress as well as silinity stress $[1(121$. Nevertheless, salinity is reported to be the mure effective stimulator of betaine accumulation $[10.3]$. In barley. nxore glycine betaine is accumulated under gradual stress, but proline is the predominant solute under sudden stress [104]. 
Table 1 Types of Compatihle Solutes That Could Accumulate Uncter Salinity Stress in Various Plant Species

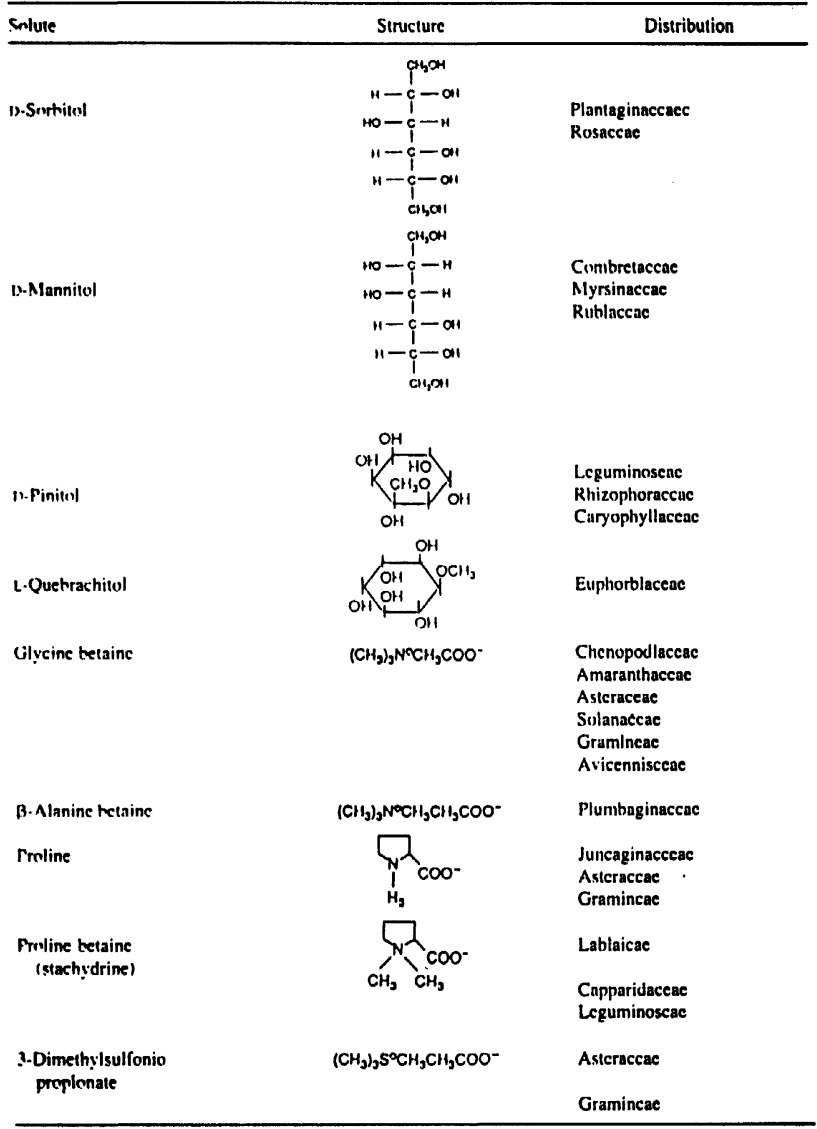

Srewre: Ref. 27. 


\section{A. Role in Osmoregulation}

High concentrations of organic solutes in the cytoplasm could contribute to the osmotic bulance when electrolytes are lower in the cytoplasm than in the vacuole $|95,105|$. These computible solutes could also act as a nitrogen source ||$(16) \mid$ or profect membranes against salt inactivation $[107,108]$. These proposed activities may complenent eich other within the integrated metubolic and ontogenic pattern of a particular species ||$(1) \mid$.

Under saline conditions, the large quantity of $\mathrm{Na}, k$, and $\mathrm{Cl}$ and other ions that are translocated to the shoot and contribute to the osmotic asljustment are believed to accumulate mainly in the vacuole after reiching lhreshold levels in the cy'toplasm |77. This concentration of inorganic ions could be considered as a threshold level at which accumulation of such organic solutes as proline, hetaine. or other compounds hegins in the cytoplasm, thus maintaining the intracellular amotic balance beween cytoplasm and vacuole $11(12)$. Fur instance, in wheat, proline began accumulating when $\mathrm{Na}+\mathrm{K}$ caceeded a threshold value of $200 \mathrm{~mm} / \mathrm{kg}$ fresh weight [IIO]. Also, in grain sorghum, a moderate level of salt stress $(0 .+\mathrm{MPa}$ or inore) is reyuired to induce a significant betaine concentration $|1| 1,1|2|$. Further studies are needed to determine the extent to which this threshold level varies among genolypes of a given species.

The total quatemary anmonium compunds (QACS) in the leaf tissue in wheat species (Triticum aestirum and 7 . durum) shows a high positive correlation with salinity treatunent 11021. The capacity to accumulate betaine in grasses has been reported to be correlated with basal levels of betaine in unstressed plants $|1| 3 \mid$. Crops such as oats and rice, which have very low betaine levels under nonsaline conditions, accumulated very little under stress conditions [102].

The relatively small increases in glycine betaine with increasing external salinity, together with the high levels found in many halophytes at very low external salinity, implies that this solute nay be redistributed tetween the valcutele and cythplasm, depending on tisste electrolyte concentrations [105]. However, in crop plants such as sorghum, it is reported that hetaine is relatively nonlabile compared to compounds such as proline 1114,115$]$. A sixfold increase in glycine hetaine levels in isclated chlor(oylasts of spinach umeler saline conditions was observed. which could atcount for $36 \%$ of the osmotic adjustment in chloroplasts |1 16 |.

Proline levels can change quickly in response to abrupt stress, while ocher organic solutes accumulate nore slowly $[112]$. Thus when stress is applied slowly, less proline accumulates. but the total accumulation of organic solutes renains predictable on the busis of tissue $\mathrm{Na}$ and $\mathrm{Cl}$ levels $(10-4)$. Accumulation of iree proline has been correlated with tissue $\mathrm{Na}$ concentration in a number of crop species $\mid 117-1191$. A level of 25 mol proline per gram fresh weight could produce a concentration of $280 \mathrm{mM} /$ if confined to cytoplasm, thus making a significant contribution to the cytoplasmic solute poltential [3].

Proline concentrations were reported to to directly proportional to Na concentrations [I 2(0): each increase in $\mathrm{Na}$ concentration is reported to he balanced by an increase in proline concentration equal to about th of the rise in $\mathrm{Na}|121|$. This relationship betueen stead)-state proline concentrations and $\mathrm{Nal}$ levels indicaltes its role as a cyloplasmic solute 11211 . I'roline

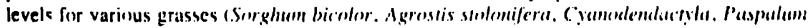

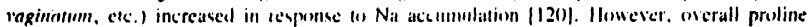
levels and accumulation rates were highly vatiable anmong glases and therefulle are not reliable

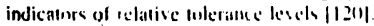

In pigeinpea. proline levels increased with increasing external salinity in two genutspes differing in their salt werance. The highes proline levels are observed at III, $1 \mathrm{~S} / \mathrm{m}$, where both genotypes died subsequently [29]. Among the wild species related to pigeonpea, there is a steady increase of proline levels with increasing external salinity in only a few' species (Figure 3). There 
Proline concentration $(\mathrm{mg} / \mathrm{g}$ fresh lit.)

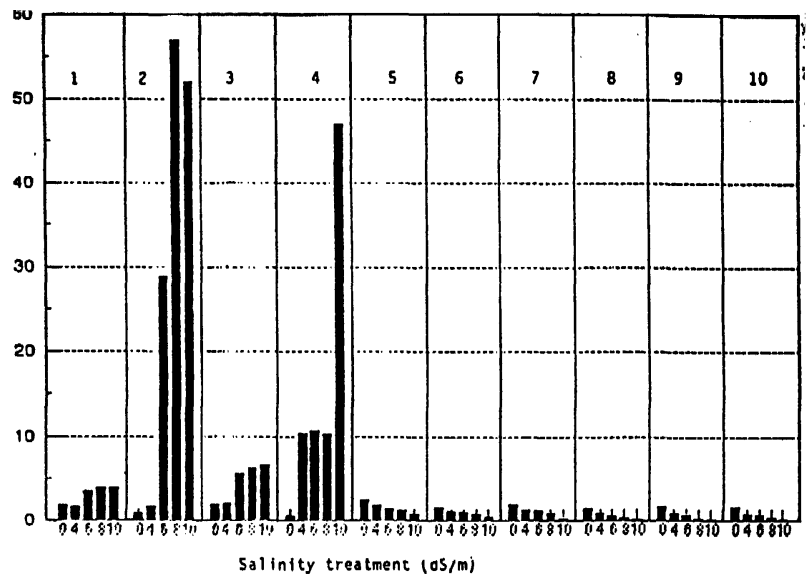

Figure 3 Proline accumulation in the wild relatives of pigconpen (Ạ̣/osia sp.) at various salinity level If enf samples were collected nt 5 ) days after sou ing.) 1. A. whicans: 2. A. sericea; 3, A. acurifolia;

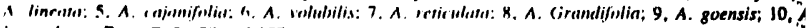
lanc colitia. IFrom Refs. 29 and 157.)

was nu clear relatiwnship telween salinity wilerance and proline accumulation, as proline accum whed to higher levels in hoth sensitive and tulerant species [29]. Similarly, some tolerant an censitive species did not accumulate significant levels of proline at any level of external salinity flins defying any simple relationship belween proline accumulation and salinity tolerance [29].

It is usually assumed that the cytoplasm comprises abuut $5 \%$ of the cell's volume, proline accumulated in the cytoplasin, and $\mathrm{Na}$ is liargely sequesicred in the vacuole [121]. Under thes conditions. proline alone could merely osmutically balance the Na. However, other ions an "rganic eslutes are also likely to be involved. as ficld salinity is often caused by a mixture of salu Thus a variety of inns. particularly K. Mg. (1r Ca. can accumulate in the cytoplasm under thos connditions. Given the wide range of organic solutes that can accumulate in different crop specie ITable I wreven amung different genotypes within a crop species. which may have a functionall similar role. it would tre unrealistic to expect any direct corrclation between salinity tolerance an accumulation of any particular organic solute, cither qualitatively or quantitatively.

\section{B. Role in lon Compartmentation}

Compatible solutes or cytocolic solutes could play an important role in regulating intracelluli inn distribution under salt stress, thus inducing $\mathrm{Na}$ accumulation in the vacuole [120]. External] 
applied glycine betaine is reported $t(1)$ increase vacuolar $\mathrm{Na}$ concentration in barley roots $[114]$. The salt concentration required for proline accumulation could be the same as is required for salts to be sequestered into the vacuole |112|. The reported threshold of about $200 \mathrm{~mol}(\mathrm{Na}+$ $\mathrm{K} / \mathrm{g}$ fresh weight) is only slightly above $(\mathrm{Na}+\mathrm{K})$ levels measured in unstressed leaves [112]. In sorghum, proline accumulation seems $w$ be related to total monovalent cation concentration whether either $\mathrm{Na}$ or $\mathrm{K}$ salts were used in the salinity treatment 1111]. An ion punip at the tonoplast could become active at about the same cytoplasmic salt concentration that activates the accumulation of proline or other organic solutes $\{112\}$.

\section{Role in Protecting Enzymes Against Monovalent Cations}

Apart from the purpose of osmoregulation, organic solutes can accumulate to protect cell metabolism from the toxic effects of accumulated ions $[3,118-120,122]$. Pollard and Wyn Jones [123] demonstrated such protection using glycine betaine and, in barley leaves, with the enzyme malate dehydrogenase (decarboxylating). Glycinebetaine has been repored to partially stabilize enzymes and membranes against a range of perturbations $\{124\}$. Proline levels up $106(1) \mathrm{mM}$ did not inhibit enzyme activity in vitro $|125|$. In harley, $1000 \mathrm{~m} / \mathrm{t}$ proline did not inhibit dehydrogenase activity 1911 . Polyribosomes are stable in vitro in glycine betaine and proline concentrations up to about $1000 \mathrm{mM} / 126)$.

Thus the effect of proline and glycine betaine on enzyme systems in the presence of inhibitory ion concentrations may he an expression of a wider role of such compounds in protein stability [91]. Most organic soluies that accumulate under stress conditions are conpatible witlı enzyme activity and continued metabolisn $\{91\}$.

Osmoregulators can not only be compatible with cytoplasmic enzymes, but can either promote or inhibit enzyme activity, depending on the cnzyme source 1127$\}$. The uffinity of phosphoenolpyruvate carboxylase (PEP' Cine) (extracted from $C$ yoden ductelon and Sporobolus pungens grown on saline soil) for PEP was increasecl by belaine and proline. which resulted in full protection against $\mathrm{NaCl}$ inhibition 11271 . Ilowever, proline did nut protect P'EP Cuse against $\mathrm{NaCl}$ when it was extracted from Salsola sola, although betaine did provide protection [127). These differences could be due to the existence of isoenzymes.

Although organic-compatible solutes may ameliorate some of the effects of accumulated ions, it seems that ion compartmentation is of grealer significance in preserving metabolic activities. In some cases the effects of compatible solutes are apparent only under severe stress and act merely as a survival trait rather than having any belleficial effect on grouth during stress [128]. But they may promote grow th recovery if these solutes protect enzyme systems against stress-induced degradation, so that they can recommence synthetic function rapidly $\{91\}$.

\section{Metabolic Costs of Organic Solute Accumulation}

Despite active accumulation of organic (smotica, there is no evidence of an additional cost, and thus osmotic adjustment exists as an cuergy-efficient and physiologically etfective device for alleviation of drought and salinity siress $|129|$. Iloweser, synthesis of organic nuelecules such as proline or hetaine dies put an alditional melabolic load on the plant. When sugars are used for osmotic adjustment, they are Int available for growith [129]. The secumulation of monstructural carton is assnciated with wmotic adjustment and uurgor maintentance $17 \mid$. Tumer [139] considers that the carbon required for osmotic adjustment would he only a small fraction of that produced by the plant. Jowever, the metabolic cost of storing photosymthate and using it for osmotic adjustment is less than the cost of converting it to new biomass, which the monstressed plants were better able to du $|129|$. This explanation was confirmed by the fact 
that there was a large increase in the respiration rate accompanied by a rapid increase init area when stressed plants were irrigated $|129|$.

From the above it appears that a varicty of organic solutes accumulate under salinityd Jrought stress conditions. Some of these compounds could the the result of passive accumulatip ii.e.. due in the general reduction in growth processes). Carbon and nitrogen compoundsfy cimply disened from grow lh-relased activitics to prinduce compounds such as proline, sucro. or ethers as a way of stering them. This avoids llic formation of tuxic compounds, such amm inia or putricine. from excess nitrogen inetabolites. However, there is evidence that soly accumulation is an active process and is very strongly regulated according to immediate pla needs as influenced by external salinity and the plant's ability to regulate ion entry into,y trancpiration ctream. Also, apart from acting as an organic osmoticum in the cytoplasm, the compatible solutes accelerate the complattmentation of $\mathrm{Na}$ and $\mathrm{Cl}$ into the vacuole, thus playis a significant role in determining the crop species level of salinity tolerance. However, it neg in the realized that (1ganic solute accumulation is unly une compenent in the overall maintenap of a stahle internal ionic environment in the cytoplasm, which would ultimately determine, survival and production pitential of $n$ crop specics grown in a saline environment. Thus, sl ahility to accumulate organic solutes would have a positive functional role only if a genoty has the "genetic know-how" to regulate ion entry, particularly of $\mathrm{Na}$ and $\mathrm{Cl}$, into the transpirati stream.

\section{N. ORGANISM INTEGRATION}

Altheough varinus prosesses that play a role in ionic and osmotic regulation al the whole pla level have tecing discussed separately. the level of salinity tolerance of a given crop speciens senoty. and $\mathrm{Na}_{\mathrm{a}}$ extrusion. $\mathrm{Na}$ compartmentation in the rost cortex. $\mathrm{Na}$ and $\mathrm{Cl}$ regulation at 4 endendermic. retricsal of $\mathrm{Na}$ from the xylem stream hy XPT. Iranspiration efficiency, preventir apoplastic accumulation. phlocm retransiocation of $\mathrm{Na}$ and $\mathrm{Cl}, \mathrm{K}$ retranslocation, organic solu occumulation. $\mathrm{Na}$ and $\mathrm{Cl}$ compartmentation in the leaf. and others. For this reason it is a surprising that no single physiological mechanism/trait shows a clcar-cut direct relationship | salinity tolerance. Genotypes may differ in one or many processes that regulate entry of Nat $\mathrm{Cl}$ iens into the plant or yualitative or quantitative differences in the organic solutes. The processes interact at the organism level to determine the ultimate level of tolerance.

\section{v. CONCEPTUAL FRAMEWORK FOR INTEGRATING PHYSIOLOGICAL ASPECTS INTO GENETIC IMPROVEMENT PROGRAMS}

There is a substantial amount of information on the physiological responses of crop plants $k$ calinity (i.e.. mostly $\mathrm{NaCl}$ ) stress. A major portion of this information deals merely with the effects of excess salts on various metaluslic functions of the plants. As Munns et al. [33] poid cut. most of this information describes only the consequences rather than the causes of reducex gmwth or injury and is thus of limited use for integration into genetic improvement programs. We telieve that there is ecope for more directed physiological research that would be mon relevant to genetic improvement considerations. Emphasis should be given to understanding the imteractions among the many possihle processes involved. and thus "organism integration." The iwo main approaches that we see for achicving this are the "black box" and "physiologica identype" approaches. 


\section{Black Box Approach}

The black box approach attempts to procecd irom established phenotspic differences fi.e., esponse to salinity) to the underlying differences in physiological mechanisms contributing (o) ligher levels of tolerance $[93,131]$. Once a surce of a higher level of salinity tolerance is dentified in the cultivated species or its wild retatives, the next step would to to transfer this olerance to agronomically acceptable varicties througl a conventional brecding approach. Since alinity tolerance is a complex pliysiological tiait, governed by different genes or groups of zenes, the problem is how best Io transfer this type of trait or ensemble of traits from the donor aarent to the recipient. A black to $x$ approacls is therefore enhanced by un understanding of the ipecific physiological traits operating in the domor parent by conducting comparative physioogical studies between donor and recipient parents. This will facilitate design of the most uppropriate genetic improvement procedures. In patticular, simple and elfective metuns of screening segregating populations for salinity lolerance are needed, rather than having to rely on the measurement of growth or yicld reduction under given levels of salinity. Identification of the predominant physiological trait or traits responsible for the genotspic dilferences ineasured is desirable.

In pigeonpea and its related wild species, there appears to be cither a curvilinear or a linear relationship between Jry malter and tissue Na ur CI levels $\left(r^{2}=0.76 ; r^{2}=0.70 ; p<0 .(\mathrm{K}) 1\right.$ : Figure $4 \mathrm{a}$ and b). However, this relationship is stronger for $\mathrm{Na}$ than for $\mathrm{Cl}$. There is a significant positive linear relationship between tissue $\mathrm{Na}$ and $\mathrm{Cl}$ levels in both shoots and roots $\left(r^{2}=0.66\right.$; $p<0.001$; Figure $4 \mathrm{e}$ and $n$. Although the uverall relationship between growth reduction and tissue $\mathrm{Na}$ or $\mathrm{Cl}$ levels appears to be positive, there is considerable variation among various wild species in the level of ionic tolerance within their tissues. This is indicated by the scatter of points. For instance, for a $50 \%$ reduction in growth, tisste $\mathrm{Cl}$ levels ranged from $<1 \%$ to ubout $4 \%$, and for $\mathrm{Na}$ it varied from $10 .(12 \%, 10$ about $1 \%$. For tissue $\mathrm{K}$ levels, we did not find any significant relationship $\left(r^{2}=0.1 \times 18\right.$; Figure $f(c)$, however, there is a positive relation between $\mathrm{K} / \mathrm{Na}$ in shoot and shoot growth $\left(r^{2}=0.73: p<0 .(\mathrm{x})\right)$; Figure $\left.4 \mathrm{~d}\right)$. Thesc data points are also very scattered, which indicates a wide range of variation among species for their optimum $\mathrm{K} / \mathrm{Na}$ requirements at a given level of growth reduction under salinity. This is not surprising given the complexity of physiological mechanisms operating in $\mathrm{Na}, \mathrm{K}$, and $\mathrm{Cl}$ regulation and the number of mitigating factors that could change the metabolic tolerance of $\mathrm{Na}$ and $\mathrm{Cl}$ levels in the tissues.

However, in comparing genotypes that dificr in their tolerance, especially anong the wild relatives of pigeonpea, we have nuticed that the ahility to retuin higher levels of $\mathrm{Na}$ and $\mathrm{Cl}$ in the roots could be one of the crucial factors in regulating their levels in the showt. This regulatury ability breaks down at salínity thresholds that valy across species alnd genorypes |29,361. Iurtluer studies have shown that this regulatory ability is expressed in the $F_{1}$ hybrids of crosses between - tolerant wild relative (Atylosia albicans) and a sensitive pigeonpea genotype (ICP 3783) (Figure 5) [36]. Thus this trait is heritable. Further studies are required on the segregating $F_{2}$ and $F_{3}$ generations, including analysis of the ionic constituents, to cstablish the inheritance pattern of these physiological traits.

\section{B. Physiological ldeotype and Pyramiding Approach}

An idestype is defined as "a hypothetical plant described in terms of traits that are thought to enhance genetic yicld potential" $|1.32|$. Thus a plysiological identype fur sulinity tolcrance coold be defined in terms of the specific physiological traits that are expected to contribute functionally in maintaining ionic and osnotic relations under saline conditions. As expressed 

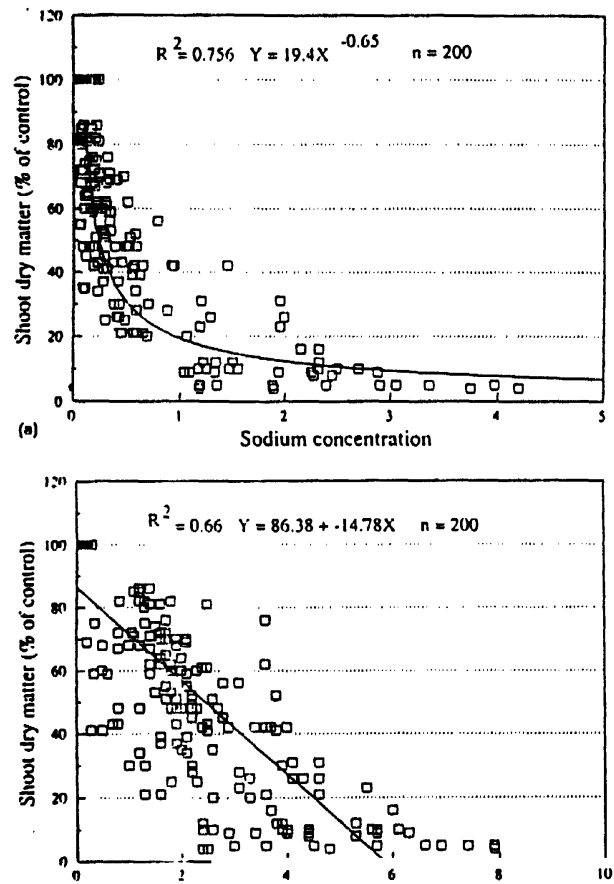

(b)

Chloride concentration

Figure 4 Relationchips beiween sheot dry matter and tissuc $\mathrm{Na}$. CI. K. and K/Na levels (a-d) and between (I and $\mathrm{Na}$ levels in riwt and slwke (e and f). (Plant samples were collecied for growth and chemical analysis nt 55 days after sexing: plants were grown at 0.. 4-. 6-. 8., and 10.dS/m salinity Jevels.) (From Ref. 157.)

in a relative yicld basis. salinity tolerance is the collective expression of a number of mysiological traits. as described carlier.

Salinity stress normally varies over time within a crop cycle, from season to season, and from site to site. Different landraces/genotypes/varictics that show a given level of tolerance to ealinity are expected to have evolved a varicty of mechanisms that contribute to yielding ability under those conditions. For instance. $T$. aestivum. Secule cereule. and Aegilops squarrosa have an efficient $\mathrm{K} / \mathrm{Na}$ selectivity character becausc of the $\mathrm{D}$ genome but are less tolerant than crop 

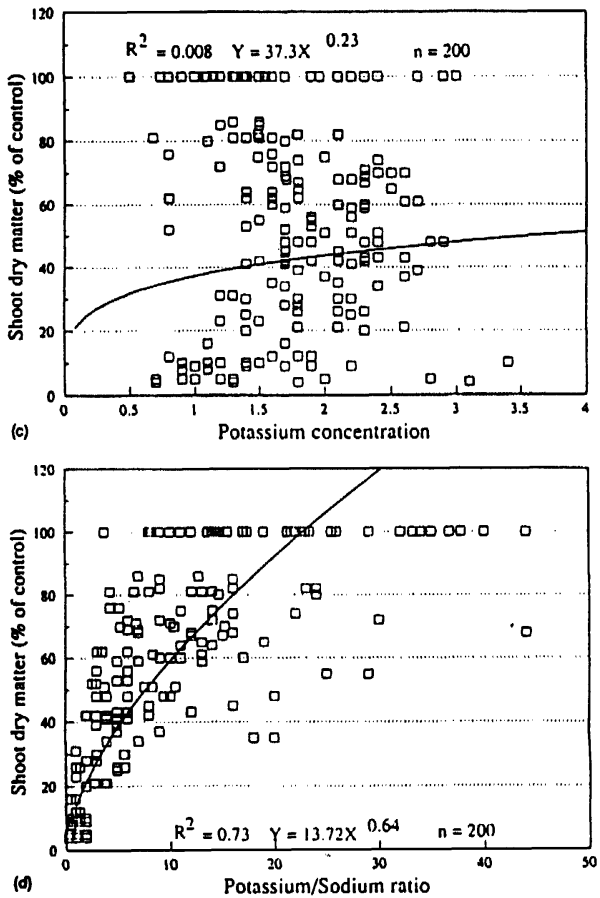

Fogure 4 (Continued)

species such as $I I$, vulgare and $T$. dum efficient in their compartmintation ability 1133.1341. Similarly, such differences can be observed among genetypes within a crop species. which is reflected in contratictory repons for varinus crop species eillor comfirming or disputing a direct correlation botween $\mathrm{K} / \mathrm{Nu}$ selectivity and level of salinity lolerance $[+1$.

The underlying philoxophy is that although different genotypes may show the same level of tolerance to salinity, they could attain this level of tolerance (i.c. phenetype) (hrough different physiolngical mechanisms or traits. Lack of sufficient phenotypic variation for salinity tolerance is a serinus prohlem in many crops, and this is particularly so with rice $|135|$. Even after 


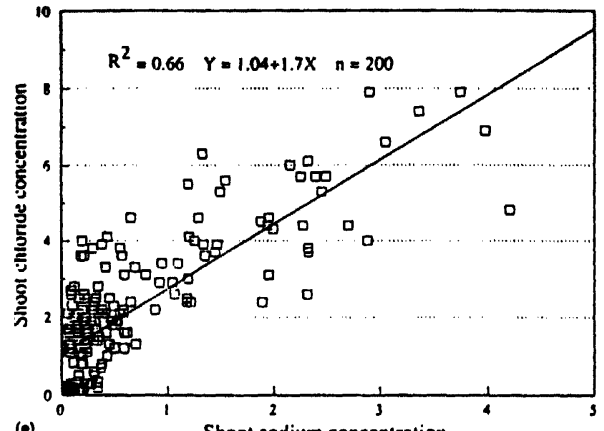

(e)

Shoot sodium concentration

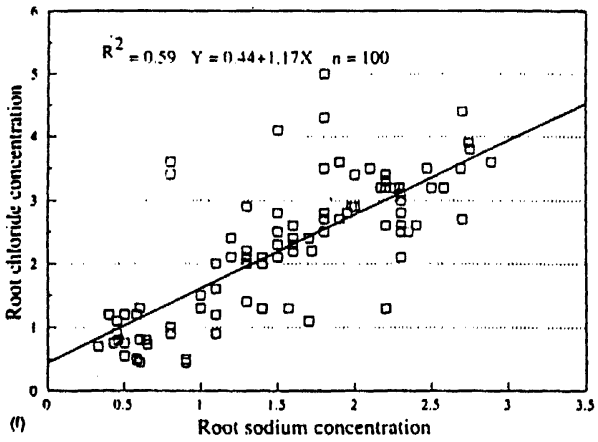

Figure 4 (C'mtinucd)

screening the entire world cullection of rice germplasm. the most tolerant genotypes would still

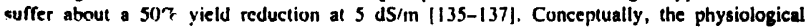
approach for improving salinity tolerance in crop plants should be to bring together the relevant Iraits that would complement each other in a pyranidic manner ("building block" approach) by their selective incorporation into a single genotype or variety under improvement (i.e., eptimization of several. probably independent. physiological mechanisms into a single variety) [19].

An analogy can be drawn from disease resistance breeding. In breeding for disease resistance. horizontal resistance (which can be defined as resistance to a number of physiological 


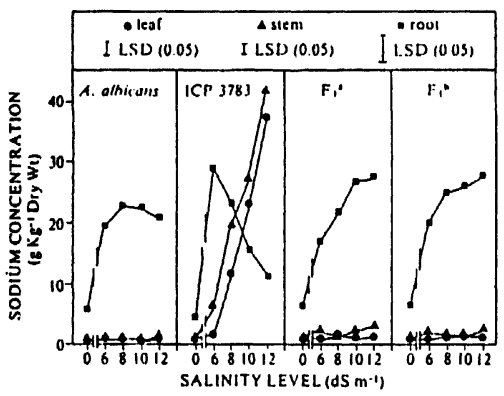

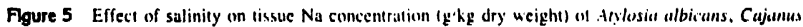
cajan (ICP 3783), and their reciprecal $F_{1}$. hybrids (al and h), 75 days after transplanting. Dutu are means of two replications. (From Ref. 36.1

races of a disease) can be achieved by pyramiding different genes specilically resistant to individual physiological races. This contributes to the stability of a genotype across years in disease-prone environments. The same concept could also be applied wi the genetic improvement of salinity tolerance, whereby pyramiding of genes that regulate various specitic physiological traits into a single genotype or variety could provide that genotype with the necessary genetic means to respomd (1) various types and levels of salinity stress that it is likel; to experience at different locations, sites, and over yeurs. This would contribute to its stability of production as well as widening its adaptahility to a greater range of saline environments.

The various steps involved in this kind of approach are:

1. Define the various physiologicar traits having functional significance in determining the tolerance and productivity of a given crop under saline environments

2. Establish genetic variability and locate sources of high efficiency for each physiological trait in the germ plasm. Selection should be directed toward the individual components of salinity tolerance on a trait-by-trait basis irrespective of phenotype.

3. Establish the genetic hasis for each physiological trait under comsideration by studying its inheritance pattern and estimating its heritability, which would determine the leasibility of using that particular trait in a breeding program.

4. Develop restriction fragment length polymorphisms (RFLP) niarkers if eusily identifiuble morphological, physiokgical, or other markers are not readily available fir each physicsIogical trait, as this would streanline the selection process of segregating muterials in a breeding progran.

5. Ietentify genotypes for each physiological trait which have geknl combining ability.

6. Incorporate relevant traits into an agromomically acceptable batiground hasis.

Information generated through this exercise could he, stored in a datahase system which would be mave available to breeders interested in incopporating salinity tulerance in their breeding pregrams. This is similar in information databases that are available for morphological 
traits from the germ plasm evaluation exerciscs at CGIAR (Consultative Group for International Africultural Research) centers.

Selection of traits to be intruduced into a given genotype/varicty under improvement: uepends on the target environment in which it will be grown, and the specific traits a particular? variety may be lacking. For instance, a variety may be very efficient in $\mathrm{Na}$ and $\mathrm{C}$ cormpartmentation in the reot as well as in the shost. but may be lacking effective $\mathrm{Na}$ or Ci. regulation at the plasmalemma. There is cvidence of genotypic variation within crop species in $\mathrm{Na}$ compartmentition in shemits $[19.138 .139\}$ and tulerance to high internal $\mathrm{Na}$ and $\mathrm{Cl}$ levelof $|(0)|$. In thic case. "Inly the trait that is lacking needs to be introduced. Similarly, a given variety may te very efficiemt in ion regulation, but lacks tlic necessary genetic incans to produce organics swlutes.

Development of RFLP markers for each of tiese physiological components of salinity inlerance could play a crucial role in the incorporation of these physiological traits into Renotype/variety utuder improvement. Salinity tulerance traits are cuntrolled by a number of genes located throughuut the chromosome compiement [140). Ench gene of a polygenic system: may contribute only a small amount (1) the trait of interest. Clear dominance is not likely to be erhibited and the plicnotype (i.e., the specific trait in this case) would have a large component: in envirenmental varriance. All these characteristics conspire to make physiological traits very! difficult to analyze. Thus conventional Mendelian methods of analysis, which are suitable for? iraits controlled by a single or a few genes. cannot be applied to analysis of these physiological traits. This is one reneon that physiological traits have not been used extensively in the genetic: improvement progranis for salinily or drought tolerance. although a number of them having: functional significance for deternining level of tolerance have been identified [6.141].

With the develipinent of RFLP mapping techniques (for a detailed discussion of RFLP ecchniques. see Tanksley et al. (|42|). it is pessible to analyze complex polygenic characters, such as physiolngical traits, as ensembles of single Mendelian factors. Since RFLP markess can the used to follow simultaneously the segregation of all chromosome segments during a crives. the hasic idea is to look for correlations thetween physiological traits and specific chromosome segments marked by RFLPs. If correlations exist, the inference is that the chrommeneme segment must be involved in the quantitative trait. The difficult part in this rriecedure is to estinhlish correlations between the trait and specific chromosome segments. The RFLP marker can ensily be scored. but the physiological trait must be characterized in a conventional fashirn ||42|. Once this most difficult process is completed and specific chromesome segments are implicated in the trait. RFLP markers with a positive effect on a 'mantitative trait can be selected from a population of plants and incorporated into a single genotype. This is pussible because of the ability to score for several RFLP marken cimultanesusly in a single plant in a manner that is free of environınental influence or gene interactions. Cartwon iscotone ('"C) discrimination, which is an indicator of water usc efficiency, cruld the predicted satisfactorily from three RFLPs in tomato [143]. We have not found any -wher repmrts implicating RFL.P markers for physiological traits contributing to salinity tolerance. The feasibility of Ising RFI.P markers for physiological traits cuuld bridge the gap between plant physiology and hreeding. to facilitate integration of these two disciplines and thus expedite development of varicties that are higher yielding and more stable across environments affected hy salinity.

\section{FUTURE OUTLOOK}

The past 30 years of research (after the report of Jual mechanisms of ion transport by Epstein et al. || $44 \mid\}$ on physinlogical aspects of salinity toleranse has contributed substantially to an 
understanding of the mechanisns by which plants cope with excess salts in their labitut. In recent times, efforts have been initiated to identify genes responsible for specific physiological mechanisms. Location of the $\mathrm{K} / \mathrm{Na}$ selectivity character on the 7 a chromosome of the $\mathrm{D}$ genome in wheat is one such example $\mid 145-147]$. Similarly. Na exclusion capability and $\mathrm{K} / \mathrm{Na}$ discrimination were enhanced in $T$. clestivum by the incorpuration of a Lophopyrum genome [148]. The K/Na discriminating locus has been located on the 3E chromosome in Lophopyrum elongatum [1 40]. An association with the higher level of salinity tolerance in dyropyron junceum has heen located in the $5 \mathrm{~J}$ chromosone $[149]$. In rice, at least three groups of genes were fuund to be involved in the inheritance of $\mathrm{Na}$ and $\mathrm{Ca}$ levels in the plant; $\mathrm{Na}$ and $\mathrm{Ca}$ levels in sherots and roots were reported to show additive affects with a high degree of heritubility (15()].

Similarly. Cl translocation is under genetic control $\mid 151,152\}$. Accumulation of organic solutes such as betaine has been reported to he regulated by a limited number of gelles $|15.3-156|$. Our research with pigeonpea has shown that the higher levels of salinity tolerance, and the associated physiological mechanisms identified in the wild relative Aṛlosict albicans, could be expressed in the reciprocal crosses of $F_{1}$ hybrids of this species with the cultivated species (Figure 5) [36\}. Information on the genetic control of specific mechanisms is essential for proper integration of physiological research into breeding programs. Recent developmerts in biotech. nology, particularly with genetic markers such as RFL.Ps, could accelerate this integration of disciplines. Wild relatives have been inadequately explored for their potential to contribute unique physiological mechanisnis of salinity folerance. We hope future efforts would be direcled toward generating information on these areas.

\section{REFERENCES}

I. D. H. Jennings, Biol, Rev.. 5/: 453 (1976).

2. D. W. Rains, Annu. Rev. Plant Physiol., 2.3: 367 (1972)

3. T. J. Flowers, P. F. Truke, and A. R. Yeo, Aumu. Rev. Plam Physiol., 28: 80 (1977).

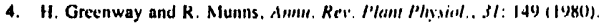

5. A. R. Yeo, Plyysiol. Plant., 58: 214 (1983).

6. W. D. Jeschke, in Suliniry Tulerance in I'lants: Strategies forl Crup Impron'sme'm (R.C. Staples and G. H. Toenniessen, eds.), Wilcy, New Y'ork, $p \Gamma$. 37-66, (1984).

7. J. M. Cheeseman, Plam! Physiol.. 87: 547 (1088).

8. H. Boyko. Salinity and Aridity: New Approaches to Old Prolslem. Dr. W. Junk. The Hague. The Netherlands (1966).

9. E. Epstein, Mtineral Nutrition of Plants. Principles and Prosplectives. Wilcy, Now York (1972).

10. P. Mitchell, Nature, 191: 144 (1961).

11. R. N. Robenson, Protons, Electrons, Phosphorylution, and Aitite Transport, Cambridge Univer. sity Press, Cambridge, (1968).

12. D. P. Briskin and J. B. Hanson, J. Exp. Bot., 4.3: 269 (1992).

13. D. T. Clarkson and C. Grignon, in Phosphorus Nurition of Gruin Legumes in the Semi-arid Trupics (C. Johansen, K. K. Lee, and K. L. Sahrawat, eds.). Intenational Crops Kescarch for the Semi-arid Tropics, Palancheru. Andhra Pradesh, India, pp. 49-62 119911 .

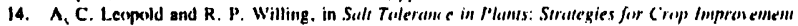
(R. C. Stuples and (j. A. Toenniessen. cils.), Wiley. New Yurk. Pp. 67-76 1/48t).

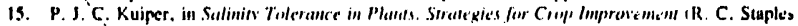
and G. A. Torenuiessen, eds.1. Wilcy. New Yomk. PN. 77-91 (1984).

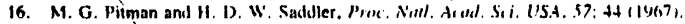

17. D. II. Jennings. New I/hstol. . 67: 899 (19)(6).

18. W. D. Seschke, in Im Tramspurt in Mlamts (W. P. Anclerson, ed.), Acadenic I'ress. New York." Pp. 285-290 (1973).

19. A. R. Yeo and T. J. Flowers, Aust. J. Plant Physiol., 13: 161 (1986). 
20. W. D. Jeschke, in Gemeric Aspects of Plant Nutrition (N. E. L. Bassam. M. Dambroth, andis C. Loughman. eds.I. Kluwer Academic Publishers, Boston, pp. 71-86 (1990).

21. R. G. Wyn Jones. C. J. Brady. and J. Speirs, in Recent Advances in the Biochemistry of Can eals (D. L. Laidman and R. G. Wyn Jones. eds.), Academic Press, New York, Pp. 63-10 (1979).

22. R. G. Wyn Jones. in Genetic Engineering of Osmoregulation: Impact on Plant Productivity fol Fond. Chemiculs, and Enerry (D. W. Rains, R. C. Valentine, and A. Hollaender, eds.), Pleana Press. New York. pp. 155-170 (1980).

23. W. D. Jeschke. in Recent Athrnces in the Biochernistry of Cereals (D. L. Loidman and R.G Wyn Jones. cus. I. Academic Press, New York, pp. 37-61 (1979).

24. J. Rozema. E. D. Ruzema. A. H. J. Freijsen, and J. J. L. Huber, Oecologia (Berlin), 34: 324 (1978).

25. J. Gorham. L. L. Hughes, and R. G. Wyn Junes, Occolugia (Berlin), 3: 309 (1980).

26. I. Ahmad, S. J. Wainwright, and G. R. Stewart. New Phytol., 87: 615 (198i).

27. J. Gorham. R. G. Wyn Jones, and E. McDunnel, Plant Soil, 89: 15 (1985).

28. M. A. Hajibagheri. D. M. R. Harvey, and T. J. Flowers. New Phyrol., 105: 367 (1987).

29. G. V. Subbarau. C. Juhansen, M. K. Jana, and J. V. D. K. Kumar Rao, J. Plant Physiol., 137 64 (1990).

30. A. Scarpa. and J, deGiez, Biochem. Biophys. Acta, 281: 789 (1971) (cited in Ref. 6).

31. A. Lauchli. in Transport and Transport Processes in Plants (I. F. Wardlaw and J. B. Passioura eds.). Academic Press. New York. pp. 101-112 (1976).

32. C. Johansen. D. G. Edwards, and J. F. Loneragan. Plant Phy:siol., 45: 601 (1970).

33. R. Munns. H. Greenuay, and G. O. Kirst, in Encyclepedia of Plant Physiology, New Series, Vol 12C. Physirlesgical rlaimt Ecologs. Vol. III (O. L.. Lange, P. S. Nubcl, C. B. Osinond, and H Ziegler, eds. I. Springer-Verlag. New York. pp. 59-135 (1983).

34. E. Epstein. in (jenetic Engineering of Osmoregulation: Impact on Plant Productivity for Food Chemicals. and Energy (D. W. Rains. R. L. Valentine, and A. Hollaender, eds.), Plenum Preas New York. Pr. 7-21 (1980).

35. D. Ksamer. A. Lauchli. A. R. Yeo. and J. Gullasch. Ann. Bot., 4l: 1031 (1977).

36. G. V. Subharao. C. Johansen, J. V. D. K. Kumar Rao, and M. K. Jana, Crop Sci., 30: 78: (I990)).

37. R. Behl and W. D. Jeschke, Physiol. Plant., 53: 95 (1981).

38. R. L. Jeffrics. in Ion Transport in Plants (W. P. Anderson, ed.), Academic Press, New Yod (1973).

39. S. M. Pan and Y. R. Chen, Bor. Bull. Acad, Sinica, 29: 33 (1988).

40. R. Weinberg. J. Biol. Chem., 242: 3000 (1967).

41. Y. D. Beletskii. T. B. Karnaukhova, and N. I. Shevyakova, Sov. Plem Physiol., 33: 890 (1986)

42. A. J. Cavalieri and A. H. C. Huang. Physiol. Plant., 41: 79 (1977).

43. S. D. Tanksley. Isozymes in Plant Genefics and Breeding. Vol. I, Elscvier, Amsterdam (1983)

44. J. L. Hall and T. J. Flowers, Plania. 110: 361 (1973).

45. T. J. Flowers. J. Exp. Bot.. 23: 310 (1972).

46. T. J. Fiowers. Fhyor hemistry. II: 1881 (1972).

47. D. H. Sennings. Ecological Aspects of the Afineral Nutrition of Plants (1. H. Rorison, ed.) Blackwell Scientific Publications. Oxford. pp. 261-279 (1969).

48. P. A. Rea and D. Sanders. Physiol. Plant., 71 : 131 (1987).

49. M. G. Palmeren. Physiol. Plant.. 83: 314 (1991).

5). M. G. Pitman. in Saliniry Tolerance in Plants: Strutegies for Crop Improvement (R. C. Staple and G. H. Teenniessen, eds, ). Wiley. New York, pp. 93-123 (1984).

51. A. Lauchli and J. Wieneke. "Salt Relations of Soybcan Mutants Differing in Salt Toleraner Distribution of lons and Localization by X-tay Micruanalysis." Plant Nutrition: Proceedings of th 8th Imernational Collonquium on Plant Analysis and Fertilizer Problems. Auckland, New Zealand Government Printer. Wellington. pp. 275-282 (1978).

52. J. G. Johansen and J. M. Cheeseman. Plant Physint.. 73: 153 (1983).

5. J. G. Johansen and J. M. Cheeseman. Plant Physiol.. 73: 159 (1983). 
54. B. J. Corvil, R. K. Dela Fuente, and R. S. Dela Pena. Plam Physiol., 40: 625 (1965).

55. A. Lauchli and J. Wiencke, Z. Pllumeenernuehr. Bentenkd., 124: 3 (1979).

56. A. R. Yeo, D. Kramer, A. Lauchli, and J. (jullasch, J. E.y. Bot., 28: 17 (1977).

57. B. Jacoby, Ann. Bol., 4.3: $741(1979)$.

58. R. T. Besford, Plant Soil. 58: 399 (1978).

59. R. Munns. D. B. Fisher, and M. L. Tennet, Aust. J. Plant Physiol., 13: 757 (1986).

60. R. R. Walker, Aust. J. Plint Physiol., 13; 293 (1986).

61. H. Nassery and D. A. Baker, Ann, Bot., 38: $141(1974)$.

62. H. Marschner and $O$. Ossenterg-Neuhaus. Z. Pflanzenernuelir. Hodenk., 1.39: 129 (1976).

63. U. Luttge, in Encyclopredin of Plum Physiolog!, New Series, Vol. 15 (A. Lauchli and R. L. Bieleski, eds.). Springer-Verlag. Berlin. pr. 181-211 (1983).

64. LE. Winter, Aust. J. Plam Physiol., 9: 239 (1)82).

65. J. J. Oerti, Agrochimica, 12: 461 (1968).

66. R. A. Leigh and R. G. Wyn Jones. New Plivtol., 97: 1 (198+).

67. R. Munn und J. B. Passioura, Aust. J. Plaut Mhysiul., 11: 479)(198-1).

68. N. J. W. Clipson, A. D. Tomos, T. J. Flowers, and R. G. Wyn Jones, Plantu, 165: 392 (1985).

69. A. R. Yen, S. J. M. Caporn, and T. J. Fowers, J. E.p. Bot., 36: 1240 (1985).

70. T. J. Flowers and Y. R. Yeo, Aust. J. Plum Physiol., 13: 75 (1986).

71. T. J. Flouers, M. A. Hajibagheri, and A. R. Yen, Plan Cell Environ., 14: 319 (1991).

72. J. S. Patc, in Transport and Transfer Processes in Plams (1. F. Wardlaw and J. B. Passioura, eds.), Acadenic Press, New York. pp. 253-281 (197h).

73. D. R. Geiger, in Transpurt and Transfer Processes in Plants (J. F. Wardlaw and J. B. Passioura, eds.), Academic Press. New York, pp. 167-183 (1976).

74. E. Levi, Physiol. Plant., 21: 213 (1968).

75. H. Lessani and H. Marschner, Aust. J. Plamt Physiol.. 5: 27 (1978).

76. E. Winter. L. Micron., 2: $519(1980)$.

77. J. A. Webb and P. R. Gorham, Plant Physiol., 39: 663 (1964).

78. H. Greenway and M. G. Pitman, Aust. J. Biol. Sci., 18: 235 (1965).

79. J. S. Patc, Encyclopedia of Plant Physieslegy, New Serics, Vol. I IA. II. Zimmerman und J. A. Milburn, eds.). Springer-Verlag, Berlin, pp. 451-473 (1975).

80. M. G. Pitman, in Ion Transpurt in Plant (e'lls and Tissues (D. A. Baker and J. L. Hall, eds.), North-Holland. Amsterdam, pp. 267-308 (1975).

81. T. J. Flowers, F. M. Sulama, and Y. R. Yco, Plam Cell Eniron., 11: 453 (1988).

82. H. Greenway, Aust, J. Biol. Sci., 18: 249 (1965).

83. M. G. Pitman, Ausi. J. Biol. Siti., 18: 9̈87 (1965).

84. D. T. F. Bowling and Weatherley. J. Exp. Bot., 16: 732 (1965).

85. M. G. Pitman, Annu. Rev. Plamt Physiol., 28: 71 (1977).

86. F. Malek and D. A. Baker, Plania. 135: 297 (1977).

87. N. G. Pitman, Aust. J. Biol. Sci., 19: 257 (1966).

88. A. Poljakoff-Mayber, in Plants in Saline Environments (A. Poljakofr-Mayber and J. Gale, eds.), Springer-Verlag, Berlin. pp. 97-117, (1975).

89. R. Stelzet and A. Lauchli, Z. Pfanzenphysiol., 84: 95 (1977).

90. A. A. Hajibagheri, J. L. Hall, and T. J. Flowers, New Phytol., 44: 125 (1983).

91. D. Aspinall, Aust. J. Plame Physiol., J3: 59) (1986).

92. N. C. Turner and M. M. Jones. in Adhuphution of Plants to Wuter and High Temperature Stress IN. C. Turner and P. J. Krancer, eds.). Wik.y, New York. pp. 87-103 (198(1)).

93. A1 Tal. Plam Soil. 89: I99 (1985).

94. A. R. Yeo, J. Exp. Bo1., 32: 487 (1981).

95. (i. K. Siewart anil J. A. L.ec. I'lumia. 120: 279 1197d).

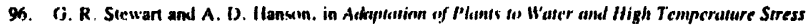
IN. C. Trurner and P. J. Kramer, eds.). Wiksy, New Youk. Pp. 173-184 (1980!.

97. S. Treichel. Z. Pflumernphysint. 76: Sh (1975).

98. A. D. Hanson and W. D. Hizz, Anmu. Ret. Phan Physiol., 33: 163 (1982).

99. C. Parameshwara, Fh.D. thesis, University of Adelaide. Australia (1984). 
I00. R. Storey and R. G. Wyn Jones, Phytochemistry, 16: 447 (1971).

101. H. Greenway. R. Mlunns. and J. Gibbs. Plam Cell Environ.. S: 405 (1982).

In2. C. M. Grieve and E. V. Maas. Physiol. Plant. 6I: 167 (1984).

In3. R. G. Wyn Jones and R. Storey. in Phisiologt und Biochemistry of Drought Resistance in Plain 1L. G. Paleg and D. Aspinall. eds.). Academic Press. Sydney. Australia, Pp. 171-203 (1981).

Ins. R. G. Wyn Jones and R. Storey. Ainst. J. Plam Physiol.. S: 817 (1978).

IIIS. Z. Kefu. R. Munns, and R. W. King. Alest. J. Plant Physiol., 18: 17 (1991).

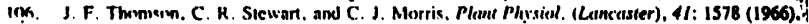

iii7. 1. Ahmad. F. Larher. A. F. Mann. S. F. McNally, and G. R. Stewart, New Phytol., 91: S8 (1982).

1198, L. G. Paleg. T. J. Druglas. A. vonDaal, and D. B. Kuch, Atst. J. Plant Physiol., 8: 107 (1981;

110. R. L. Jeffrics and T. Rudmik. in Salinity. Tolerunce in Crop Plants: Strategies for Crop Improvemat IR. C. Staples and (i. H. Tuenniessen. eds.). Wiley. New York, pp. 213-227 (1984).

IIn. R. Weinterg. Physiol. Plant., 73: 418 (1988).

III. R. Weimterg. H. R. Lerner. and A. Poljakurt-Mayber, Physiol. Plant. 55 : 5 (1982).

112. G. Voctherg and C. R. Stewart. Phum Physiol.. 76: 567 (1984).

113. W. D. Hits and A. D. Hanson, Phylochemistry, 19: 2371 (1980).

114. N. Ahmad and R. G. Wyn Jones, Plant Sci. Lett. 15: 231 (1979).

115. A. D. Hansem and C. E. Nclson. Plemi Plissiol. . 62: 305 (1978).

116. S. P. Robinson and (j. P. Juncs. Aust. J. Plam Physiol.. 13: 659 (1980).

117. R. Weimterg. H. R. Lemer, and A. Poljakoff-Mayber. Physiol. Plamt., $62: 472$ (1984).

11R. J. Levitt. Rerymses of Plants io Environmentul Siresses, Vol. II Water, Sall and Other Siresse. 2nd ed.: Academic Fress. New York (1980).

119. R. G. Wyn Jones. R. Storey. R. A. Leigh. N. Ahmad, and A. Pollard, in Regulation of Ce Afembrane Activities in Plants (E. Narre and U. Cieferti, eds.). North-Holland, Amsterdam, P1 121-135 (1977).

120. W. A. Torello and L. A. Rice. Plunt Soil. 93: 241 (1986).

121. T. J. Flowers and A. R. Yen. in Envirnnmental Stress in Plams: Biochemical and Physiologica. Mlechanisms is. H. Chern, ed.). NATU ASI Scrics. Serics G. Ecolugical Sciences, Vol. 19 Springer-Verlag. New York. pp. 101-119 (1989).

122. H. Greenway and A. P. Sims, Aust. J. Plant Physiol.. I: 15 (1974).

12.3. A. Pollard and R. J. Wyn Jones, Plamtn. 144: 291 (1979).

124. R. G. Wyn Jones. Recent Adlances in Phylot hemistr. Vol. 13. Phytochemical Adaptations a Siress (B. N. Timnerinan. C. Sieclink, and F. A. Luewis. cds.), Plenum Press, New York, Pp 55-78 (1984).

125. M. I. Lone. J. S. H. Kuch. R. G. IV yn Jones, and S. W. J. Bright. J. Exp. Bot., 38: 479 (1987)

126. C. J. Brady. T. S. Gitson. E. IV. R. Barlow, J. Speirs, and R. G. Wyn Jones, Plant Cell Environ. i: 371 (1984).

127. Y. Manctac. Y. Petripusulure, and G. Karabourniotis, Plant Cell Environ., 9: I45 (1986).

12R. C. Lai and 1. G. Pilcg. Phumt Siri. Lett., 25: 329 (19k2).

129. K. J. MicCrce. Aurt, J. Plam Plussiol. IJ: 33 (1986).

13. N. C. Turner. in Sterss Phwsiolingr in Crop Plimes (li. Alussell and R. C. Staples, eds.), Wiley New Yiork. Fp. 344-372(1979).

131. R. A. Fischer. Plont Soil, 58: 249 (1981).

132. D. C. Rasmusson. Crop Sci.. 27: 1140 (1987).

133. J. Gorham. J. E.rp. Bet.. 41: 623 (1990).

134. J. Gorham. A. Briskel, E. M. Young. R. G. W. Jones, and G. Kashour, J. Exp Bot., 41: 109 (1990).

135. A. R. Yeo, M. E. Yco, S. A. Flowers. and T. J. Flowers, Theor. Appl, Genet., 79: 377 (1990)

136. S. Yoshida. Fundamentals of Rice Crop Science. International Rice Research Institute, Los Banos The Philippines (1981).

137. A. R. Yeo. K. S. Lec. P. Izard. P. J. Boursier. and T. J. Flowers. J. Exp Bot., 42: 881 (1991)

13A. T. J. Flowerv. E. Dugue, M. A. Hajibagheri, T. P. McGenigle, and A. R. Yeo. New Phytol. (10): 37 (19k5), 
139. Y. Suranga, J. Rudich, und D). Zamir. Aitu Ilortic... 2(K): 2113) (1987).

140. J. Dvarak, E. Epstein, A. Galvez. P. (iulick, and J. A. Unielan, "Genetic Basis of Plant Tinleranes

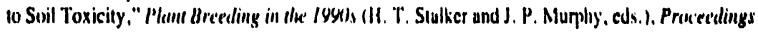
of the Symposium an Plam Hiceding in the 1990. Noth Carolina Statc University, Mar. IY9I. CAB International, Wellinpford, Berhshite. England, pp. 2(1)-217 (199?).

141. M. M. Ludlow and J. M. Mluchow, Ad1. Asrom., f.1: $1(17$ (I99)).

142. S. D. Tanksley, N. D. Young. A. II. Palceswn, and M. W. Bunicrbale, Biolech. 7: 257 (1989).

143. B. Martin, J. Nicnhuis, (J. King, and A. Schaefler, Science, 2+3: 1725 (1989).

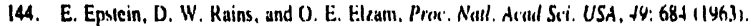

145. R. Storey, R. G. Ciraham, and K. WV. Shepherd, Mlem Sovil, 8.3: 323 (1985).

146. S. H. Shah, J. Gorhain, B. P. Forster, R. (i. W. Jones, and R. G. IVyn Jines, I. I. W. Ihol., 38: 254 (1987).

147. J. Gorham, C. Hardy, R. C. W. Jones, L. R. Jopps. C. N. Law, and R. G. W'jull Junes, Theor'. Appl. Genet., 74: $58+$ (1987).

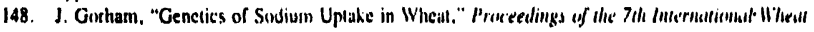
Gentetics Symposium. pp. 817-821 (ty88).

149. D. P. Schachiman. A. J. Bloom, and J. Dvorak, I'kum ('rll Emirom.. I2: 17 11989).

150. M. Akbar, G. S. Khush, and D. Hilleristambers, in Rice Genetics, Intcrnational Rice Reseurch Institute, Manila. The Philippines, pp. 334-f(1) (1986).

151. G. H. Abel, Crop Sti.. 9: 607 11969$)$.

152. A. V. Venables und D). A. Wilkins, New Phy/ul. . 8(1); 61311978).

153. R. Gnumet, T. G. Isleib, and A. D. Itansen, (rop Si i. 2.5: 618 (1985).

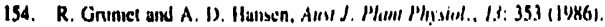

155. S. A. Quarric, Mlam Cell Emiron., ل: 147119811.

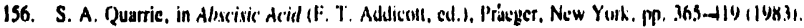

157. G. V. Subbarao, Ph.D. dissertation, Indian Institule of Technology, Khurazpur, India (|У४४). 